\title{
Infrastructure Classification Revisited
}

\author{
Mohammed Aliu Momoh, Ph.D. \\ Department of Finance, University of Lagos, Akoka. Lagos \\ alimomoh@gmail.com
}

\begin{abstract}
The impact infrastructure has long been viewed as a key ingredient for economic development. Though it has a strong growth promoting, the enormous need and complexity of infrastructure has made it difficult to define. The infrastructure definition and classification debate has been on for decades. Scholars have argued that and viewed the issue of definition and classification from different perspective ranging from aggregation to the need to reconcile the analytic and not necessarily compatible objectives. This paper reconciles the issues around the description and classification of infrastructure. It examined the various classification overtime, taking cognizance of the issues of appropriate description to meet policy challenges.
\end{abstract}

Keywords: Institutional Infrastructure, Personal Infrastructure, Material Infrastructure, Infrastructure Policy

Subject Classification: JEL: J10, H54, O12, P10

Language: English

Date of Submission: 2018-03-25

Date of Acceptance: 2018-04-20

Date of Publication: 2018-04-30

ISSN: 2321-1091

Volume: 12 Issue: 01

Journal: JOURNAL OF SOCIAL SCIENCE RESEARCH

Website: https://cirworld.com

This work is licensed under a Creative Commons Attribution 4.0 International License 
The impact of an adequate supply of infrastructure services has long been viewed as a key ingredient for economic development, starting with the seminal work of Aschauer (1989) and subsequent policy debate. Calderón and Servén (2008) found that infrastructure development - as measured by an increased volume of infrastructure stocks and an improved quality of infrastructure services - has a positive impact on long-run growth and a negative impact on income inequality. Therefore, access to infrastructure services plays a key role in helping reduce income inequality and key determinants of overall growth and the magnitude and productivity of capital inflows to liberalizing economies (Hill 2004).

According to Age nor (2010) Infrastructure have a strong growth-promoting effect through their impact on production costs, so also a significant literature that supports the argument that infrastructure promotes economic development and growth, attracts a significant positive effect on economic growth with increasing returns to scale, foreign direct investment (FDI), reductions in production costs in manufacturing, significantly higher growth rates and poverty reduction (Dutt and Ravallion 1998; Elhance and Lakshamanan, 1988; Sahoo and Saxena, 1999; Sahoo, 2006 and Udah, 2011).

However, the enormous need and complexity of infrastructure has made it difficult to define (Age nor 2010, ADB 2012, Infrastructure Canada 2007). The difficulty in having a universally or common definition is bore out of the need to reconcile the three analytic and not necessarily compatible objectives identified by Buhr (2003) as, the formulation of a concept for the term "infrastructure", the incorporation of theoretic approaches and the description of the reality of infrastructure provision.

This paper therefore seeks to reconcile the issues around the description and classification of infrastructure. In doing this, the next part describes infrastructure, then proceed to examine the various classification overtime taking cognizance of the issues of appropriate description to meet policy challenges.

\subsection{INFRASTRUCTURE DEFINED}

The word 'infrastructure' which MacMillan (1992) described as the structural elements of an economy that facilitate the flow of goods and services between buyers and sellers came into current use in the 1950s when the military applied it to their permanent installation. Since then, it has come to be referred to the subordinate parts of almost every technological system (Cain 1997). Infrastructure is a broad concept with no universally recognized or common definition. It is largely perception subject matter driven. (Nijkamp, et al. 2000; Buhr 2003; UNCTAD 2008; Torrisi 2009 and Morimoto, 2010).

The World Bank (2005) describes infrastructure as an umbrella term for many activities. It plays a very important role for industrial and overall economy and a "means for ensuring the delivery of goods and services that promote prosperity and growth and contribute to quality of life including the social well-being, health and safety of citizens, and the quality of their environments" (OECD 2007, 13).

According Drosdowski, et al (1997), traditionally, "infrastructure" has been applied to permanent installations required for military purposes, however modern general usage of the term is concerned with the necessary economic and organizational foundation of a highly developed economy. This Jimenez (1994) observed is the foundation on which the factors of production interact in order to produce output and considered to include, "those services without which primary, secondary and tertiary production activities cannot function. In its wider sense, it includes all public services from law and order through education and public health to transportation, communications, power and water supply, as well as such agricultural overhead capital as irrigation and drainage systems" (Hirschman 1958, 83).

Prud'homme (2004) describes infrastructure as consisting of capital goods which are not consumed directly; they provide services only in combination with labour and other inputs. They are very long lasting, space specific, involving long gestation periods, few substitutes in short run periods, very capital intensive and usually 
associated with market failures. Infrastructures are generally thought of as those facilities owned by government or by private, regulated utilities that are used in the delivery of either public goods or the production of services (Crandall 1997; Nijkamp 2000 and Baldwin and Dixon 2008).

Infrastructure development is one of the major factors contributing to overall economic development, creating production facilities, stimulating economic activities, reduces transaction and trade costs, improving competitiveness, providing employment opportunities and positively affecting the poor directly and indirectly in multiple ways (World Bank 1994; Jones 2004; Estache 2006; Dasha and Sahoob 2010). Though it has been established that there is no commonly agreed usage of the term infrastructure, the concept, can in its broadest sense, comprises the physical facilities, institutions and organizational structures (UNCTAD 2008) designed towards facilitating economic growth of a nation.

Torrisi (2009) submitted that though there is a general consensus around the idea that infrastructures are important features related to economic performance, opinions however differ on the magnitude. The next section discusses the issues around the evolution and classification of infrastructure

\subsection{CLASSIFICATION OF INFRASTRUCTURE}

In earlier studies, aggregation of infrastructure according to Da Silva, et al (1987) was common. Tinbergen (1962) introduces the distinction between infrastructure (e.g., roads and education) and superstructure (comprising manufacturing, agricultural and mining activities). However since around the early 1990s, infrastructure has been disaggregated into its component parts, - two components (Highway and Education or Core Infrastructure and Non-Core Infrastructure or productive and unproductive infrastructure), three components (Highway, Water Supply and Disposal, and Others), four components (Agriculture, Industry, Transportation, Telecommunication and General Welfare) six components (Industry, Living, Environment, Education, Agriculture and Land Security); (Mera, 1974; Munnell 1990; Garcia-Mila and McGuire 1992; Evans and Karras 1994; Mitsui, et al. 1995; Aschauer 1989; Ida and Yoshida 1999 and Torrisi 2009).

OECD (2004) on its part listed infrastructure as water distribution, power generation \& distribution, gas production \& distribution, roads \& railways, and telecommunications while the American Society of Civil Engineers (ASCE) considers infrastructure as aviation, bridges, dams, drinking water, energy, hazardous waste, navigable waterways, public parks \& recreation, rail, roads, schools, security, solid waste, transit and wastewater. Hansen (1965) and Fourie (2006) on the other hand distinguish infrastructures into economic and social according to the fact that they act on the level of economic development of a territory in direct or indirect way. However, little justification for selecting these areas is provided. Others have attempted to include environmental and human capital, yet the reasons behind such selection are often unclear (Baldwin and Dixon 2008)

However, Jochimsen (1966) disaggregated infrastructure, distinguishing between materials, institutional and personal infrastructure. He defined infrastructure "as the sum of material, institutional and personal facilities and data which are available to the economic agents and which contribute to realizing the equalization of the remuneration of comparable inputs in the case of a suitable allocation of resources, that is complete integration and maximum level of economic activities" (Jochimsen 1966, 100). This categorization or classification has become important because according to Buhr (1977), it make it possible to distinguish between the effects and the determinants of infrastructure, specifying each approach by the category of infrastructure under investigation. This is classification adopted in this paper

\subsection{Material Infrastructure}

Material infrastructure refers to the capital stocks that serve the function of mobilizing the economic potentialities of economic agents. They are those immobile, non-circulating capital goods that essentially contribute to the production of infrastructure goods and services needed to satisfy basic physical and social requirements of economic agents and unavailable to the individual economic agents (households, firms etc.) 
(Buhr 2003 and Buhr 2009). According to Buhr (2009), Material infrastructure is characterized by two distinguishing qualities. The first trait refers to the essential prerequisites of human life and the second distinguishing quality of material infrastructure is the non-availability of infrastructure goods and services to the individual household or firm for production and cost reasons.

Transition economies are facing serious challenges in terms of physical infrastructure and everyday business decisions are made based on infrastructure performance. Moreover, business and commerce depend on material infrastructure (roadways, waterways, pipelines, electricity lines, and broadband connections) to transport goods and raw materials, gain access to and provide services, communicate, and function. There is no doubt that strong infrastructure performance can ultimately support economic efficiency (Vagliasindi 2004; Cambridge Systematics 2008 and Oswald et al 2011)

These infrastructures are expected to play an important role in the catching-up process of developing and transition countries, unfortunately has become one of the main challenges that firms face on a daily basis, costing up to four times higher than they are in OECD countries and making infrastructure one of the main concerns for entrepreneurs (Estache et al. 2002; vonHirschhausen 2002; World Bank 2005; Gonzalez et al. 2007). For instance, Calderon and Serven (2004) found positive and significant output contributions of three types of infrastructure assets - telecommunications, transport and power to economic development. Similar studies by Roller and Waverman (2001), Dutta (2001), Ding and Haynes (2006), Shiu and Lam (2004) Calderon and Serven (2004) and Rud (2012) confirm this relationship.

Zhai (2010) opined that with annual investment of around US\$800 billion in transport, communication, and energy infrastructure during 2010-2020, developing Asia is likely to reap welfare gains of US $\$ 1,616.3$ billion (in 2008 prices) in 2020 , or $10 \%$ of its projected aggregate gross domestic product (GDP) that year. These benefits are expected to be particularly strong in two types of economies in the region, those with a high level of dependence on external trade, and those where conditions require expeditious investment to upgrade their infrastructure.

\subsection{Institutional Infrastructure}

One of the universal key responsibilities of governments is to protect their citizens against harm and exploitation, and it has been widely argued that a country's economic performance over time is determined to a great extent by its political, institutional and legal environment (OECD 2001 and Ojah and Mokoaleli-Mokoteli 2012). Institutional infrastructure according to Jochimsen $(1966,117)$ "comprises the grown and set norms, institutions and procedures in their reality of constitution, insofar as it refers to the degree of actual equal treatment of equal economic data, excluding meta-economic influences. It determines the framework within which economic agents may formulate their own economic plans and carry them out in co-operation with others".

According to Decuir-Viruez (2004), Institutions provide the framework for socioeconomic development, examining constraints and opportunities, influence all activities and define possibilities of growth. They reduce uncertainty in exchange, garner consensus and common arrangements and guide individual action. This category of infrastructure include formal institutions such as rules, laws, constitutions, property rights, as well as informal ones such as individual habits, groups' routines, customs, traditions, social norms and values as well as the facilities and procedures for guaranteeing and implementing these rules by the state. They help to define the country's investment environment, and thus create favorable conditions for economic growth and determine the forms of social relationships and the incentives that modify human interaction (North 1991; Globerman and Shapiro 2002; Buhr 2003 and Decuir -Viruez 2004).

Often held as a precondition for economic development, investments in institutional infrastructure not only attract capital, but also create the conditions under which domestic multinational companies emerge and invest abroad. In developing countries, they have generally been successful in improving sector performance in terms of higher investment and service availability, efficiency, higher quality of life, and thus attract foreign direct investment (FDI) and have been favorable to the development and implementation of new views, approaches, 
techniques and practices (List 2001; Smarzynska and Wei 2001; Wheeler 2001; Globerman and Shapiro 2002; Gutierrez 2003; Maiorano and Stern 2007)

Development of an economy is anchored on the level of innovation. For real innovation, organizational and policy learning are needed, requiring institutional changes and careful strategic governance, especially when such innovations introduce shifts in fundamental ways of thinking and acceptance at various levels and sociopolitical acceptance in particular (North 1990; Tompkins and Adger 2005). Garcia-Murillo and Kuerbis (2005) posited that the private sector would be unable to make long-term plans if it fears possible expropriation, thus supporting the submission of Acemoglu et al. $(2003,2005)$ that institutional arrangement is the key determinant of the joint evolution of economic and political developments because policy uncertainties discourage investment.

This become very important because the development of predictable and transparent institutional frameworks would ensure users' access to competitively price, high quality services and would engender investment in the infrastructure sectors with assurances that the market outcome is as close as possible to the one that would be achieved in a fully competitive environment. This places constraints on political actors, limiting the potential for arbitrary policy change (Henisz 2002; Vagliasindi 2004 and Carmona 2010). This thus corroborates the injunction of the President Barack Obama to African government to build strong institutions rather than focus on personalities (Songwe 2017).

\subsection{Personal Infrastructure.}

Personal infrastructure refers to "... the number and the qualities of people in the market economy characterized by the division of labour with reference to their capabilities to contribute to the increase of the level and the degree of integration of economic activities" (Jochimsen, 1966, 133).

Buhr (2003) opined that personal infrastructure is exemplified by the number of (quantitative personal infrastructure) and the properties (qualitative personal infrastructure) of the working population that influence the economic potentialities of the economic agents. The realized potentialities determine again the properties of the economic agents (learning by doing in a wide sense). A general way to refer to personal infrastructure is human capital; defined as by $\operatorname{OECD}(2001,18)$ as the "knowledge, skills, competencies and attributes embodied in individuals that facilitate the creation of personal, social and economic well- being".

The role of the personal infrastructure in economic development, as a stimulus for technical progress and for investment in physical capital has been stressed in the economic literature (Bils and Klenow 2000; Duflo 2001; Krueger and Lindahl 2001; López-Bazo and Moreno 2008). Lucas (1988) asserts that economic development is related to the knowledge accumulation process, which produces an institution or social capital represented by the average knowledge resulting in increased productivity. Similarly, improvement in social infrastructure, such as education and health, can sustain the service-led growth that depends mainly on the availability of skilled and productive human power. It is therefore essential to promote better utilization of physical infrastructure and human resources, thereby leading to higher economic growth and improving quality of life (Hall and Jones 1999; De and Ghosh 2003).

Hall and Jones (1999) argue that international differences in levels of output-per-worker are determined by differences in human capital, physical and social infrastructure. This submission is reinforced by Hanushek and Woessmann (2008), which established that, that there is a robust relationship between human capital and economic growth and development. Further, Wagstaff (2002) noted that up to 1.7\% of annual economic growth in East Asia between 1965 and 1990 (about half the total GDP increase for the period) for instance has been attributed to massive improvements in public health and education thus supporting the findings of Foster and Rosenzweig (1996) that education improves labour productivity, facilitates technological innovation, increase returns to capital and help to improve health outcomes. 
Suri, et al. (2010) therefore suggested that improving human development must precede or accompany rising economic growth for a country to reach sustained growth. In terms of policy sequencing, without improvements in human development, policy that attempts to enhance economic growth is highly unlikely to lead to sustained growth. East/ Southeast Asian countries have made rapid improvement in their macroeconomic situations, investment, exports and employment over two and half decades because of a huge investment in physical and social infrastructure (Straub et al. 2008).

\subsection{CONCLUSION}

The challenges of infrastructure classification have thrown up issues that have significant impact on definition. Interestingly, while previous classification, the two, three and six components, as well as the OECD, ASCE examples, placed more emphasis on the materiality component of infrastructure classification, Hansen (1965) and Fourie (2006) as earlier highlighted tried to capture infrastructure classification within the sphere of material and personal infrastructure. All these descriptions left out an important component which is institutional.

Though there have been various arguments like Glaeser et al. (2004) submission that personal infrastructure is more important for growth than the institutions, that the responsibility for the provision of institutional infrastructure is considered to be a task of the state, while recent development suggest that the private sector in principle, are taken to be responsible for supplying personal infrastructure and material infrastructure through a public private partnership arrangement, considering that privately owned firms are more efficient and more profitable than otherwise-comparably state-owned firms. The role of Government however cannot be excluded in the provision of these infrastructures (de Fraja1993; Megginson and Netter 2001).

However, the tripod classification of infrastructure as exposed above thus makes it easy to appreciate the policy input and requirements in the economic planning process. This has support in the submission of Adams Smith (1776) that no one individual can provide infrastructure suggesting that all the economic agents rely on a common platform from which payment is shared. It is the submission of this paper that the tripod classification therefore provides the circle that builds the economy, as no one is more important than the other.

\section{References}

Acemoglu, D., Johnson, S., Ronbinson, J., Tchaichoroen, Y., 2003. Institutional causes, macroeconomic symptoms, volatility, crises and growth. Journal of Monetary Economics 50, 49-123.

Acemoglu, D., Johnson, S., Robinson, J.A., 2005. Institutions as the fundamental cause of long-run growth. In: Aghion, P., Durlauf, S. (Eds.), Handbook of Economic Growth. Elsevier, North Holland, chap. 6.

Age nor P-R 2010. A Theory of Infrastructure-Led Development. Journal of Economic Dynamics \& Control 34 (2010) 932-950.

Aschauer, D. A. 1989. "Is Public Expenditure Productive?" Journal of Monetary Economics 23: 177-200.

Asian Development Bank 2012 Infrastructure for Supporting Inclusive Growth and Poverty Reduction in Asia. Mandaluyong City, Philippines: Asian Development Bank.

Baldwin J. R. and Dixon J. 2008. Infrastructure capital what is it? Where is it? How much of it is there? The Canadian productivity review. Statistics Canada;

Bils, M. and Klenow, P. J. 2000. Does schooling cause growth? American Economic Review, 90(5), 1184-1208.

Buhr W 1977 Materielle, personelle und institutionelle Infrastruktur. In: Woll A (Hrsg.) Fünf Jahre Gesamthochschule Siegen, Konzept und Wirklichkeit. Gesamthochschule Siegen, Siegen, pp. 162-177 
Buhr, W 2003. What is infrastructure? University of Siegen. Discussion Paper No. 107-03.

Buhr, W. 2009. Infrastructure of the Market Economy Discussion Papers in Economics No. 132-09.

Cain, L. P. 1997. Historical perspective on infrastructure and US economic development. Regional Science and Urban Economics 27 117-138

Calderon, C. and Servon, L. 2004. 'The Effect of Infrastructure Development on Growth and Income Distribution', World Bank Policy Research Working Paper no. 3400.

Calderón, C., and Servén, L. 2008. Infrastructure and economic development in Sub-Saharan Africa. World Bank Policy Research Working Paper 4712.

Cambridge Systematics. 2008. The transportation challenge: Moving the U.S. economy (Prepared with Boston Logistics Group, Inc. and Alan E. Pisarski, report to U.S. Chamber of Commerce, Chamber Foundation and Americans for Transportation Mobility). Alexandria, VA: National Stone, Sand \& Gravel Association.

Carmona, M 2010. The regulatory function in public-private partnerships for the provision of transport infrastructure. Research in Transportation Economics 30 110-125

Crandall, R. W 1997. Are telecommunications facilities 'infrastructure?' If they are, so what? Regional Science and Urban Economics 27 (1997) 161-179.

Dasha, R. K and Sahoob, P 2010. Economic growth in India: the role of physical and social infrastructure. Journal of Economic Policy Reform Vol. 13, No. 4, 373-385

Da Silva Costa, J., R. W. Ellson and R. C. Martin 1987 "Public Capital, Regional Output, and Development: Some Empirical Evidence," Journal of Regional Science, Vol.27, No.3,

Pp. 419-437De, P. and Ghosh, B. 2003. How do infrastructure facilities affect regional income? An investigation with South Asian countries. Discussion Paper 66, Research and Information System for Developing Countries (RIS), New Delhi, India

De Fraja, G 1993 Productive efficiency in public and private firms. Journal of Public Economics 50: 15-30

Decuir -Viruez, L 2004 Measuring the Institutional Factors in The Economic Growth of The Mexican Regions 1970-2000. Paper to be presented at the 44rd ERSA Congress 2004 on REGIONS AND FISCAL FEDERALISM. University of Porto, Portugal

Ding L. and Haynes, K.E., 2006. The role of infrastructure in regional economic growth: the case of telecommunications in China, Australasian Journal of Regional Studies, 12(3), 165-187

Drosdowski, G., Scholze-Stubenrecht, W., Wermke, M 1997 Duden Fremdwörterbuch. Verlag Bibliographisches Institut \& F A Brockhaus AG, Mannheim. In Buhr, W (2003). What is infrastructure? University of Siegen. Discussion Paper No. 107-03.

Duflo, E. 2001. Schooling and labor market consequences of school construction in Indonesia: Evidence from an unusual policy experiment. American Economic Review, 91(4), 795-813.

Dutt, G. and Ravallion, M., 1998. Why have some Indian states done better than others at reducing rural poverty. Economica, 65, 17-38.

Dutta, A. 2001. Telecommunications and economic activity: An analysis of Granger causality. Journal of Management Information Systems, 17, 71-95. 
Elhance, A.P. and Lakshamanan, T.R., 1988. Infrastructure production system dynamics in national and regional systems: an economic study of the Indian economy. Regional science and urban economics, 18 (4), 511-531.

Estache, A. 2006. Infrastructure: a survey of recent and upcoming issues. Washington, DC: The World Bank

Estache, A., Foster, V., Wodon, Q 2002. Accounting for poverty in infrastructure reform: learning from Latin America's experience. World Bank Institute Development Study, World Bank, Washing- ton, DC

Evans, P., and Karras, G. 1994. Are government activities productive? Evidence from a panel of US states. The Review of economics and statistics, 1-11.

Foster, A. D. and Rosenzweig M. R. 1996. 'Technical Change and Human Capital Returns and Investment: Evidence from the Green Revolution', American Economic Review pp.931-953.

Fourie, J 2006. Economic Infrastructure: A Review of Definitions, Theory and Empirics. South African Journal of Economics Vol. 74:3

Garcia-Murillo, M., and Kuerbis, B. 2005. The effect of institutional constraints on the success of universal service policies: a comparison between Latin America and the World. Telecommunications Policy, 29(9), 779-796.

Garcia-Mila T and McGuire T J. 1992 The Contribution of Publicly Provided Inputs to States Economies. Regional Science and Urban Economics June 22(2): 229-41

Glaeser, E.L., La Porta, R., Lopez-de-Silane, F., Shleifer, A 2004. Do institutions cause growth? Journal of Economic Growth 9 (1), 271-303.

Globerman, S and Shapiro. D. 2002. Global Foreign Direct Investment Flows: The Role of Governance Infrastructure. World Development Vol. 30, No. 11, pp. 1899-1919.

Gonzalez. J., Guasch, J. L., and Serebrisky, T 2007. Latin America: High Logistics Costs and Poor Infrastructure for Merchandise Transportation, World Bank, mimeo.

Gutierrez, L.H., 2003 The effect of endogenous regulation on telecommunications expansion and efficiency in Latin America. Journal of Regulatory Economics 23 (3), 257-286.

Hall, R and Jones C. 1999. Why Do Some Countries Produce So Much More Output per Worker than Others? Quarterly Journal of Economics, 114: 83-116

Hansen, N. M. 1965. "The structure and determinants of local public investment expenditures." Review of economics and statistics 2: 150-162.

Hanushek, E. A. and Woesmann, L. 2008. 'The Role of Cognitive Skills in Economic Development', Journal of Economic Literature 46, pp.607-88

Henisz, W.J., 2002. The institutional environment for infrastructure investment. Industrial and Corporate Change 11 (Number 2), 355-389

Hill, H. 2004. Six Asian Economies: Issues and Lessons. In Brooks, D.H. and H. Hill, Eds. Managing FDI in a Globalizing Economy: Asian Experiences, London: Palgrave Macmillan, pp. 29-78. 
Hirschman, A. O. 1958. The Strategy of Economic Development. New Haven: Yale University Press. In, Jimenez, E. (1994) Human and Physical Infrastructure: Public Investment and Pricing Policies in Developing Countries. Policy Research Working Paper 1281. Policy Research Department. The World Bank

Ida, T., and Yoshida, A. 1999. Productivity of disaggregate effects public capital (Shakai shihon no bumonbetsu seisanryoku koka). JCER Economic Journal (Nihon Keizai Kenkyu), 38, 107-129

Infrastructure Canada 2007. Infrastructure and Productivity: A Literature Review. Transport Infrastructure and Communities Portfolio, Government of Canada. Research and Analysis Division Infrastructure

Jimenez, E. 1994 Human and Physical Infrastructure: Public Investment and Pricing Policies in Developing Countries. Policy Research Working Paper 1281. Policy Research Department. The World Bank

Jochimsen, R., Ed. 1966. Theorie der Infrastruktur: Grundlagen der marktwirtschaftlichen Entwicklung. Tübingen, J.C.B. Mohr: In Torrisi, G. (2009). Public infrastructure: definition, classification and measurement issues.

Jones, S. 2004. Contribution of infrastructure to growth and poverty reduction in East Asia and the Pacific. Background paper, Oxford Policy Management, October.

Krueger, A. B and Lindahl, M. 2001. Education for growth: Why and for whom? Journal of Economic Literature, 39(4), 1101-1136

List, J. A. 2001. US county-level determinants of inbound FDI: evidence from a two-step modified count data model. International Journal of Industrial Organization, 19, 953-973.

López-Bazo, E and Moreno, R. 2008. Does human capital stimulate investment in physical capital? Evidence from a cost system framework. Economic Modeling 25; 1295-1305

Lucas, R. 1988. On the Mechanics of Economic Development". Journal of Monetary 26 Economics 22: 3-42.

MacMillan 1992. Dictionary of modern economics. 4th ed. Palgrave Macmillan Publisher.

Maiorano, F and Stern, J. 2007. Institutions and telecommunications infrastructure in low and middle-income countries: The case of mobile telephony. Utilities Policy $15165-181$

Mera, K. 1973. II. Regional production functions and social overhead capital: An analysis of the Japanese case. Regional and Urban Economics, 3(2), 157-185.

Megginson W L and Netter J M 2001 From State to Market: A Survey of Empirical Studies on Privatization. Journal of Economic Literature 39: 321-389

Mitsui, K., Takezawa, Y., and Kawauchi, S. 1995. Regional allocation of public capital (Shakai shihon no chiikikan haibun: Seisan kansu no suikei). Productivity of public capital and fiscal policy (Shakai Shihon np Seisansei to Kouteki Kinyu) Nohon Hyoronsha (in Japanese), Tokyo, 97-130

Morimoto, R. 2010. Estimating the benefits of effectively and proactively maintaining infrastructure with the innovative Smart Infrastructure sensor system. Social-Economic Planning Sciences 44. 247-257

Munnell Alicia H 1990. How does Public Infrastructure Affect Regional Economic Performance? New England Economic Review 11-32.

Nijkamp P 2000. Infrastructure and Suprastructure in Regional Competition: A Deus Ex Machina? In: Batey P W 
J, Friedrich P (eds.) Regional Competition. Springer-Verlag, Berlin, Heidelberg, New York, pp. 87-107

Nijkamp, P, Ubbels, B., and Koetse, M 2000. Infrastructuur als portfolio: een duurzaamheidsvisie op infrastructuur. In Wiegmans, B. W. et al. (2005) Concessions to PPP? A perspective on infrastructure development in the EU.

North, D.C. 1990. Institutions, institutional change, and economic performance. New York: Cambridge University Press.

North, D. 1991. "Institutions". Journal of Economic Perspectives, Vol. 5, No. 1. (Winter, 1991), pp. 97-112.

Ojah, K and Mokoaleli-Mokoteli, T 2012. Internet financial reporting, infrastructures and corporate governance: An international analysis. Review of Development Finance

Organization for Economic Cooperation and Development 2001. The well being of nations: the role of human and social capital. OECD, Paris.

Organization for Economic Cooperation and Development 2004. Futures Project on Global Infrastructure Needs. OECD Paris.

Organization for Economic Cooperation and Development 2007 Infrastructure to 2030, Vol.2

Oswald, M., Li, Q., McNeil, S., and Trimbath, S 2011. Measuring Infrastructure Performance: Development of a National Infrastructure Index. Public Works Management \& Policy 16(4) 373-394

Prud'homme, R. 2005. Infrastructure and Development Lessons of Experience. Proceedings of the 2004 Annual Bank conference on Development Economics. 153-181.

Roller, L. and Waverman, L 2001 Telecommunications infrastructure and economic development: A simultaneous approach. American Economic Review, 91, 909-923;

Rud, J. P 2012 Infrastructure regulation and reallocations within industry: Theory and evidence from Indian firms. Journal of Development Economics, Vol. 99, No. 1

Sahoo, P. 2006. FDI in South Asia: trends, policy, impact and determinants. In: Asian development bank institute discussion paper series, no. 56. Tokyo: ADB.

Sahoo, S. and Saxena, K.K., 1999. Infrastructure and Economic Development: Some Empirical Evidence. The Indian Economic Journal, 47, 39-57.

Shiu, A. and Lam, P-L. 2004. Electricity Consumption and Economic Growth in China, Energy Policy, 32: 47-54

Smarzynska, B. K. and Wei, S. J. 2001. Pollution havens and foreign direct investment: dirty secret of popular myth. National Bureau of Economic Research Working Paper No. W8465, NBER, Cambridge, MA

Smith, A. 1776. An Inquiry into the Nature and Causes of the Wealth of Nations. 2 Vols, Everyman's Library. London: Dent \& Sons (1904); In Calitz, E and Fourie, J (2007). Infrastructure in South Africa: Who is to finance and who is to pay? Stellenbosch Economic Working Papers: 15/07

Songwe, Vera 2017 From strong men to strong institutions: An assessment of Africa's transition towards more political contestability. Africa in Focus, Brookings

Straub, S., Vellutini, C., and Warlters, M. 2008. Infrastructure and economic growth in East Asia. World Bank Policy Research Working Paper 4589. 
Suri, T., Boozer, M. A., Ranis, G., and Stewart, F 2010 Paths to Success: The Relationship Between Human Development and Economic Growth. World Development. Vol. 39, No. 4, pp. 506-522, 2011

Tinbergen, J 1962. Shaping the World Economy, Suggestions for an International Economic Policy. The Twentieth Century Fund, New York.

Tompkins EL and Adger WN. 2005 Defining response capacity to enhance climate change policy. Environ Sci Policy 8:562-71.

Torrisi, G. 2009. Public infrastructure: definition, classification and measurement issues. Available online at http://mpra.ub.uni-muenchen.de/12990/1/Survey_infra_def.pdf.

Udah, E. B. 2011. Constraints to Economic Development and Growth in Nigeria European Journal of Scientific ResearchISSN 1450-216X Vol.65 No.4 (2011), pp. 581-593

United Nations Conference on Trade and Development (UNCTAD) 2008. Transnational Corporations and The Infrastructure Challenge. World Investment Report 2008: United Nations Conference on Trade and Development.

Vagliasindi, M 2004. The role of investment and regulatory reforms in the development of infrastructure across transition economies. Utilities Policy 12 303-314

vonHirschhausen, C., 2002 Modernizing infrastructure transformation economies: Paving the way to European enlargement. Edward Elgar, Cheltenham, UK, Northampton, MA, USA.

Wagstaff, A. 2002. Health spending and aid as escape routes from the vicious circle of poverty and health. HNP Discussion Paper, World Bank, Washington, DC.

Wheeler, D. 2001. Racing to the bottom? Foreign investment and air pollution in developing countries. World Bank Working Paper no. 2524, World Bank, Washington DC

World Bank. 1994. World Development Report 1994: infrastructure for development. New York: Oxford University Press

World Bank 2005. Infrastructure and the World Bank: A Progress Report. World Bank.

Zhai, F 2010. The Benefits of Regional Infrastructure Investment in Asia: A Quantitative Exploration. ADBI Working Paper Series No. 223. 